\title{
Incidence of Anosmia among Covid 19 patients in India
}

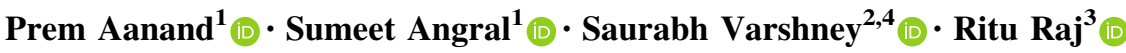

Received: 18 April 2021 / Accepted: 17 May 2021/Published online: 3 June 2021

(C) Association of Otolaryngologists of India 2021

\begin{abstract}
The pandemic COVID-19 has relentlessly caused havoc to human life since its outbreak in December 2019. The disease has been a challenge for all. The clinical manifestations of Covid-19 ranges from no symptoms at all to severe acute respiratory distress syndrome. Anosmia being one of the important clinical features of COVID-19 has always been overlooked by the Indian population. This formed the background for this study. Aim To identify the incidence of anosmia reported in COVID- 19 patients in India. Materials and Methods Literature search was carried out from January 2020 to March 2021 in databases like PUBMED and Google Scholar using the key words "ANOSMIA", "HYPOSMIA" and "OLFACTORY DYSFUNCTION" in conjunction with "COVID-19", "SARS-COV-2", and "CORONAVIRUS". Boolean operators were used to narrow and broaden the search. The
\end{abstract}

Saurabh Varshney

drsaurabh68@gmail.com

Prem Aanand

premdebull@gmail.com

Sumeet Angral

angralsumeet@gmail.com

Ritu Raj

rtrj82@gmail.com

1 Department of Otorhinolaryngology \& Head-Neck Surgery, All India Institute of Medical Sciences, Deoghar, India

2 Department of Otorhinolaryngology \& Head-Neck Surgery, All India Institute of Medical Sciences, Deoghar, India

3 Department of General Medicine, All India Institute of Medical Sciences, Deoghar, India

4 Department of Otorhinolaryngology \& Head neck Surgery, All India Institute of Medical Sciences, Deoghar, Jharkhand 814142, India search yielded sixteen eligible articles. Result The scrutiny of the 16 articles revealed an incidence range of anosmia from $9.2 \%$ to $82 \%$ and an average anosmia incidence rate of $30.19 \%$. The cumulative incidence rate of anosmia in those studies where objective analysis was done is $52.2 \%$ and $16.4 \%$ for subjective analysis. Discussion The prevalence of anosmia in Indian population is found to be much lesser than that reported by European countries due to ethnicity or negligence. Objective evaluation of anosmia in COVID-19 patients increases the incidence of anosmia drastically. Hence objective evaluations such as UPIST, SNIFFING STICK test, etc. is to be promoted. This study also Emphasises the lack of common gold standard testing for olfaction like vision and hearing.

Keywords Anosmia · COVID-19 - SARS-CoV-2 . Olfaction disorders

\section{Introduction}

COVID-19 the raging pandemic and a threat to mankind is caused by severe acute respiratory syndrome corona virus2 [SARS COV-2]. Isolated from the throat swab sample of a patient in Wuhan city China back in Jan 7, 2020 [1]. The impact of COVID-19 was catastrophic, as of march 2021 the weekly epidemiological update from WHO reports over 102 million cases and a total toll of deaths to 2.2 million from 222 countries and territories [2]. India notified its first laboratory-confirmed case of SARS-CoV-2 from the state of Kerala in the later part of January 2020. As on April 2021 globally India ranked second in terms of burden of COVID-19 cases, with 13 million cases including 170,179 deaths. SARS COV2 belongs to the $\beta$-genus of the Coronaviridae family. Being an enveloped single standard 
RNA virus with genome of 26-32 kilobases [3, 4] they have characteristic club-shaped spikes that project from their surface made of S protein with S1 and S2 subunits that makes the virus attach to the cell membrane by interacting with host ACE2 receptor [5]. The clinical manifestations of Covid-19 ranges from no symptoms at all to severe acute respiratory distress syndrome and death. The most common symptoms include fever, cough, dyspnoea, sore throat, headache, myalgia, rhinorrhoea and diarrhoea and nasal discharge [6]. Epidemiological importance is given to asymptomatic patients as they play a key role in community transmission of the disease. Otolaryngologic symptoms forms most of the symptomatology of asymptomatic COVID-19 patients with reports suggesting that anosmia and taste disturbance being the only manifestation in "asymptomatic" individuals [7].

\section{Anosmia}

Anosmia is defined as the complete loss of olfactory sensation, about $5 \%$ of the general population have anosmia and it increases with age. The sense of smell called olfaction is essential for any living being. Studies of late suggests that olfactory dysfunction impacts the quality of life (QOL) adversely and it can affect the elements of QOL such as safety, hygiene, and nutrition [8]. Olfactory dysfunction can be classified as quantitative and qualitative (Table 1). The principle causes of olfactory dysfunction include: trauma, viral infections, rhinosinusitis, neurodegenerative illnesses-Parkinson disease, Alzheimer dementia [9].

Table 2 describes the different characteristics of olfactory dysfunction. Anosmia associated with post viral URI [Rhino and Para-influenza virus] occurs along with rhinorrhoea and nasal block due to mucosal inflammation.
Exceptionally the anosmia in COVID-19 doesn't have the aforementioned nasal symptoms [10, 11]. Thereby indirectly suggesting a correlation between SARSCOV-2 infection and damage to the chemosensory system [12]. There are increasing evidence worldwide that olfactory dysfunction could be the presenting complaint in COVID19 patients without rhinorrhoea, nasal block before appearance of other symptoms like fever and cough [13]. This has lead the way for increasing research in COVID-19 associated anosmia resulting in addition of new onset anosmia in the list of pre-existing clinical symptoms of COVID-19 by Centres for Disease Control and Prevention [14].Though exact pathophysiology behind COVID-19 induced anosmia is blurred and extensive research work is carried on to attain clarity. Olfactory dysfunction in COVID-19 infection could be related to the involvement of the olfactory bulb or damage to the peripheral olfactory receptor cells in the nasal neuroepithelium as SARSCOV-2 is neurotrophic in nature [15]. Various animal models have demonstrated high levels of angiotensin converting enzyme (ACE2) proteins expression by nasal and olfactory support cells which is used by the SARS-CoV-2 to infect the cells [16].

The olfactory epithelium includes several distinct cell types, namely, horizontal basal cells [HBCs], microvillar cells [MVCs], Bowman's gland cells [BGCs], globular basal cells [GBCs], olfactory unsheathing glia [OEGs], sustentacular cells [SUSs], immature olfactory sensory neurons [iOSNs] and mature olfactory sensory neurons and [mOSNs, respectively [23]. The OSNs possess the receptors for perception of smell [22, 24]. In humans, there are at least $\sim 400$ functionally distinct OSNs [25]. Olfactory sensation starts when the odoriferous substance reaches the olfactory cleft and dissolve through the nasal mucosa to binds to the receptors on the dendritic cilia of olfactory sensory neurons (OSNs). The 6-30 million OSN has a

Table 1 Classification of olfactory dysfunction (52)

\begin{tabular}{ll}
\hline $\begin{array}{l}\text { Olfactory } \\
\text { dysfunction } \\
\text { (dyosmia) }\end{array}$ & \\
\hline Quantitative & Hyperosmia \\
Normosmia & Oversensitivity \\
Hyposmia & Normal sensitivity \\
$\begin{array}{l}\text { Anosmia (functional anosmia } \\
\text { specific anosmia) }\end{array}$ & $\begin{array}{l}\text { Reduced sensitivity } \\
\text { Complete anosmia: absolute loss of olfactory function, no smell detectable }\end{array}$ \\
& $\begin{array}{l}\text { Functional anosmia: severe limitation of olfactory function includes complete loss as well as } \\
\text { residual odour perception }\end{array}$ \\
& $\begin{array}{l}\text { Partial anosmia: greatly reduced sensitivity to a particular Odoriferous substance/group of } \\
\text { substances compared with General population usually not viewed as pathological }\end{array}$ \\
Qualitative & Altered perception of odours in the presence of a stimulus \\
& Perception of odours in the absence of stimulus \\
\hline
\end{tabular}


Table 2 :Characteristics of posttraumatic, post-viral \& sinonasal related olfactory dysfunction (52)

\begin{tabular}{|c|c|c|c|}
\hline & Head injury & $\begin{array}{l}\text { Infection of the } \\
\text { upper respiratory } \\
\text { tract }\end{array}$ & Rhinitis/sinusitis \\
\hline Probable cause & $\begin{array}{l}\text { Lesion of the olfactory Fibres in the } \\
\text { region of Lamina cribrosa,contusion } \\
\text { Of brain areas relevant to olfaction }\end{array}$ & $\begin{array}{l}\text { Viral damage of olfactory } \\
\text { epithelium }\end{array}$ & $\begin{array}{l}\text { Mechanical displacement, oedema/ } \\
\text { functional defect because of } \\
\text { inflammatory process of the } \\
\text { mucosa/olfactory bulb }\end{array}$ \\
\hline $\begin{array}{l}\text { Isolated odour } \\
\text { impressions }\end{array}$ & Rare & Frequent & Frequent \\
\hline Epithelium & Degeneration & $\begin{array}{l}\text { Metaplasia,faulty development } \\
\text { of ORN }\end{array}$ & Signs of inflammation, mostly normal \\
\hline $\begin{array}{l}\text { Rate of occurrence } \\
\text { of Olfactory } \\
\text { dysfunction }\end{array}$ & Around 5\% & Less than $1 \%$ & 60 of all patients with chronic sinusitis \\
\hline Age & $20-50$ years & $45-65$ years & $30-60$ years \\
\hline $\begin{array}{l}\text { Onset of olfactory } \\
\text { Dysfunction }\end{array}$ & Rapid & Rapid & slow \\
\hline Olfactory loss & Severe & Moderate & Variable \\
\hline $\begin{array}{l}\text { occurrence of } \\
\text { parosmia }\end{array}$ & Frequent & Very frequent & Rather rare \\
\hline $\begin{array}{l}\text { Likelihood of } \\
\text { regression of } \\
\text { olfactory } \\
\text { dysfunction }\end{array}$ & Infrequent & Frequent & Very frequent \\
\hline
\end{tabular}

special characteristic of continuously renewing themselves from the basal cells. OSNs convey odour related information to the first relay station, olfactory bulb and from there, information is further carried to higher brain centres to complete odour perception. Conscious perception of odours are relayed to the orbitofrontal cortex [17-20] with interconnections to the limbic system, cerebellum and insula.

The novel coronavirus, SARSCoV-2, enters the host cell by binding angiotensin-converting enzyme-2 [ACE2] receptors followed by priming of the viral spike protein by the Transmembrane Protease Serine 2 [TMPRSS2] [19]. Interestingly, single-cell sequencing studies reveal expression of ACE2 and TMPRSS2 in human olfactory epithelial supporting [sustentacular] cells, but not in OSNs $[16,21,22]$. A structural study using the cryo-electron microscopy [EM] unravelled the strong interaction between the full-length viral spike protein and the human ACE2 receptor [23, 24]. Hypothetically anosmia could be a due to increased viral load in SUSs, BGCs and OSCs which are located apically in the olfactory epithelium, initially SUS cells might be infected, leading to partial/complete breakdown of the olfactory architecture, resulting in the decline in olfaction.

The insufficient data on the incidence of anosmia in COVID-19 from Asia more so from India formed the design for this study to be undertaken.

\section{Objective}

Considering the importance of smell disturbances in COVID 19, the study was undertaken by reviewing articles published in PUBMED and GOOGLE SCHOLAR to identify the incidence of anosmia among COVID-19 patients in India. The study aims at sorting out discrepancies in the incidence values of anosmia among COVID patients in India. 


\section{Material and Method}

\section{Search Strategy and Selection Criteria}

The literature search was carried out in databases like PUBMED and google scholar from January 2020 to March 2021. The search terms used were: "ANOSMIA", "HYPOSMIA" and "OLFACTORY DYSFUNCTION" in conjunction with "COVID-19", "SARS-COV-2", and "CORONAVIRUS". Boolean operators (NOT, AND, OR) were also used. Full text articles reporting the incidence of anosmia in COVID-19 patients from INDIA were included in the study. Articles which do not mention ANOSMIA and those that do not include INDIAN patients were excluded from the study.

\section{Data Extraction and Analysis}

A total of 1756 records were identified through the search from January 2020 to March 2020. After removing duplicate records 883 records were screened. After initial screening 435 articles were removed as they were non otolaryngological topics. The remaining 448 articles were taken for assessment and eligibility. 432 full text articles were excluded as they dealt with non-Indian population. Hence the remaining 16 articles were included in the study based on the inclusion criteria. The details of the data collection are presented in the Prisma chart. (Fig. 1)

\section{Results}

The number of patients included in the eligible studies varies from 34 to 1263 . The age of patients varied from 15 to 43 years with a mean of 38.52 . Except one study all other studies had adult patients. The patients included in studies screened were suffering from mild to moderate forms of the disease as the ventilated and intensively cared patients could not report anosmia. The range of incidence as observed by the studies ranges from $9.2 \%$ to $82 \%$ and the average incidence rate acquired in this study is $30.19 \%$. Review of the articles gives an incidence rate of $52.2 \%$ for quantitative analysis and $16.4 \%$ for subjective analysis. This was supported by a meta-analysis done by Manish Mair who gives an incidence rate of $42 \%$ for quantitative analysis and 37\% for subjective analysis. Another systemic review by Ajai Prakash stated an incidence rate of $48.54 \%$ $(25,27)$. Nine studies out of the 16 have said that anosmia is associated with dysgeusia of varied severity. It is also evident from the review that objective evaluation of anosmia in COVID-19 patients increases the incidence of

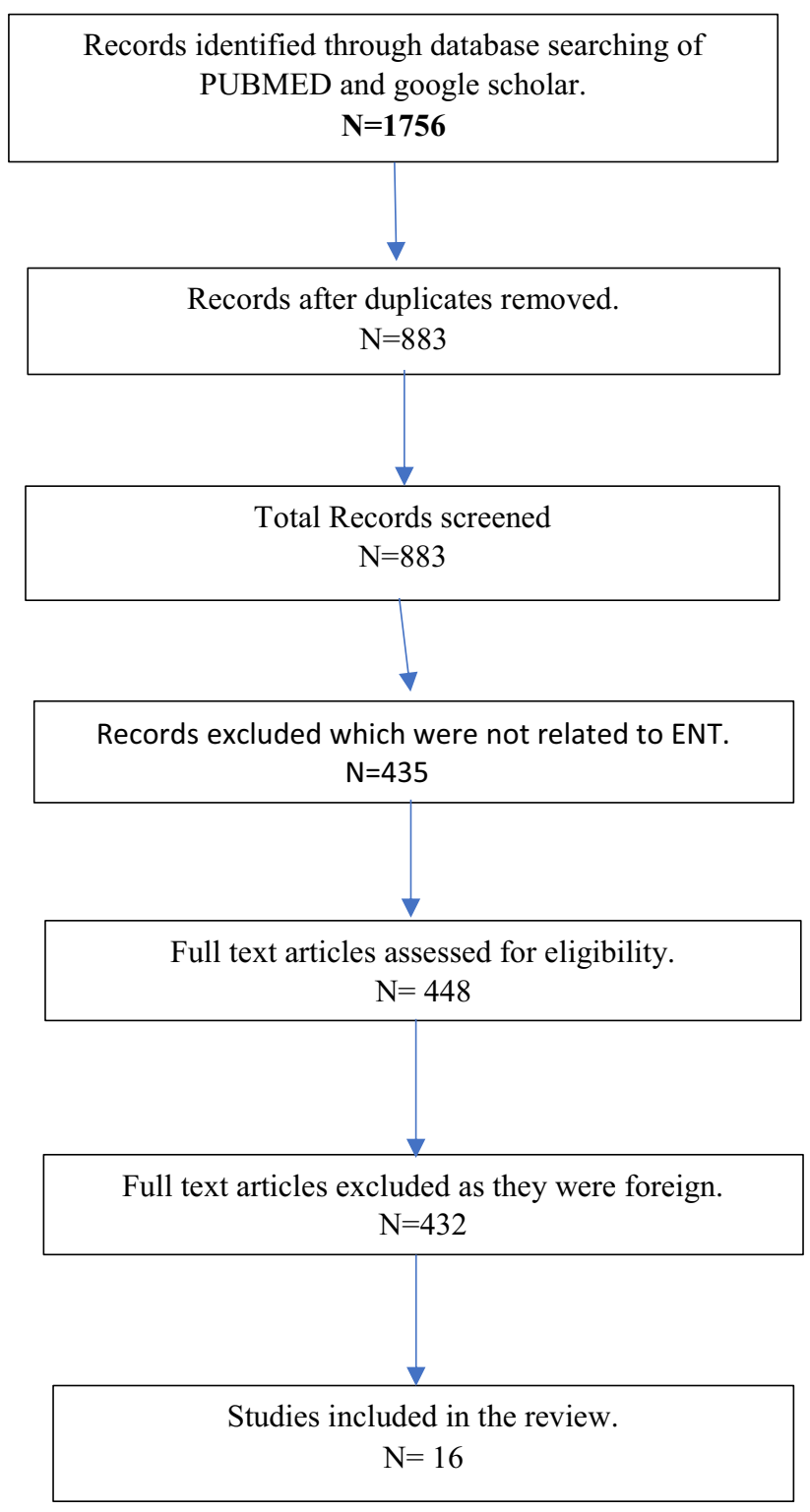

Fig. 1 Prisma chart

anosmia drastically. There is no significant gender predominance in the incidence rate of anosmia as observed by the review. It was found in the review that anosmia does not have any association with comorbidities like systemic hypertension and type II diabetes mellitus. Table 3 Summarizes characteristics of included studies.

\section{Discussion}

The first cranial nerve "Olfactory nerve" also regarded as the forgotten cranial nerve has always been overlooked during examination in clinical practices. Besides anosmia [in the absence of intranasal diseases such as infectious rhinosinusitis, allergic rhinosinusitis, vasomotor 
Table 3 Showing characteristic summary of studies reviewed

\begin{tabular}{|c|c|c|c|c|c|c|c|c|c|c|}
\hline S.no & Date & Author & Country & Study method & $\begin{array}{l}\text { Number of } \\
\text { patients }\end{array}$ & $\begin{array}{l}\text { Mean } \\
\text { age }\end{array}$ & $\begin{array}{l}\text { Anosmia diagnosis } \\
\text { method }\end{array}$ & $\begin{array}{l}\text { Incidence } \\
\text { rate }(\%)\end{array}$ & $\begin{array}{l}\text { Gender } \\
\text { Predominance }\end{array}$ & $\begin{array}{l}\text { Dysgeusia } \\
\text { related }\end{array}$ \\
\hline 1 & $\begin{array}{l}\text { Jul } \\
\quad 2020\end{array}$ & $\begin{array}{l}\text { Prasun } \\
\text { Mishra }\end{array}$ & India & Case-control & 74 & N/A & Self-reported & 14.8 & Nil & No \\
\hline 2 & $\begin{array}{l}\text { Sep } \\
2020\end{array}$ & $\begin{array}{l}\text { AJain, } \\
\text { L Kumar }\end{array}$ & India & Cross- sectional & 410 & 38 & Eliciting history & 21.1 & Nil & Yes \\
\hline 3 & $\begin{array}{l}\text { Sep } \\
2020\end{array}$ & Lakshit Kumar a & India & prospective & 141 & 15.2 & Self-reported & 24.1 & $\mathrm{~N}$ & Yes \\
\hline 4 & $\begin{array}{l}\text { Sep } \\
2020\end{array}$ & $\begin{array}{l}\text { Anindya S. } \\
\text { Bhattacharjeea, }\end{array}$ & India & Case-control & 34 & $\mathrm{n} / \mathrm{a}$ & $\begin{array}{l}\text { Quantitative using } \\
\text { olfactometer }\end{array}$ & 82 & Nil & No \\
\hline 5 & $\begin{array}{l}\text { Sep } \\
\quad 2020\end{array}$ & Indu Rajkumar & India & $\begin{array}{l}\text { Prospective } \\
\text { cross- } \\
\text { sectional }\end{array}$ & 230 & 43 & $\begin{array}{l}\text { Qualitative using } \\
10 \text { odours }\end{array}$ & 41.3 & Nil & Yes \\
\hline 6 & $\begin{array}{l}\text { Oct } \\
2020\end{array}$ & Vijay Bidkar1 & India & cohort & 76 & 28 & $\begin{array}{l}\text { Qualitative test } \\
\text { using } 3 \text { odours }\end{array}$ & 81.6 & Nil & Yes \\
\hline 7 & $\begin{array}{l}\text { Oct } \\
2020\end{array}$ & Smriti Panda & India & cohort & 225 & 35 & Self-reported & 12.5 & Nil & No \\
\hline 8 & $\begin{array}{l}\text { Oct } \\
2020\end{array}$ & $\begin{array}{l}\text { Naveed Nazir } \\
\text { Shah }\end{array}$ & India & Cross sectional & 121 & 33 & Questioner & 18.47 & Nil & No \\
\hline 9 & $\begin{array}{l}\text { Nov } \\
\quad 2020\end{array}$ & $\begin{array}{l}\text { Narayanasamy } \\
\text { Krishnasamy }\end{array}$ & India & Cohort & 1263 & 35 & Self-reported & 9.4 & Nil & No \\
\hline 10 & $\begin{array}{l}\text { Nov } \\
2020\end{array}$ & Betsy varghese & India & Cross sectional & 203 & 36 & Self-reported & 12 & Nil & No \\
\hline 11 & $\begin{array}{l}\text { Nov } \\
2020\end{array}$ & Nishanth Dev & India & Case control & 261 & 36 & Self-reported & 21.1 & Nil & Yes \\
\hline 12 & $\begin{array}{l}\text { Nov } \\
2020\end{array}$ & Vishav Yadav & India & $\begin{array}{l}\text { Prospective } \\
\text { observational }\end{array}$ & 152 & 43 & Questioner & 18.4 & Nil & Yes \\
\hline 13 & $\begin{array}{l}\text { Nov } \\
\quad 2020\end{array}$ & $\begin{array}{l}\text { Priyanka } \\
\text { Chaurasia }\end{array}$ & India & $\begin{array}{l}\text { Prospective } \\
\text { observational }\end{array}$ & 727 & N/A & Self-reported & 12.10 & Nil & yes \\
\hline 14 & $\begin{array}{l}\text { Jan } \\
2021\end{array}$ & $\begin{array}{l}\text { Pradipt Ranjan } \\
\quad \text { Sahoo }\end{array}$ & India & Cross sectional & 77 & 37 & Eliciting history & 10.1 & Nil & Yes \\
\hline 15 & $\begin{array}{l}\text { Jan } \\
2021\end{array}$ & Kunal Thakur & India & $\begin{array}{l}\text { Prospective } \\
\text { observational }\end{array}$ & 250 & 40 & Questioner & 72 & Nil & No \\
\hline 16 & $\begin{array}{l}\text { Jan } \\
\quad 2021\end{array}$ & Disha Kou & India & $\begin{array}{l}\text { Prospective } \\
\text { observational }\end{array}$ & 300 & 37 & Self-reported & 27.6 & Nil & Yes \\
\hline
\end{tabular}

rhinosinusitis and nasal polyposis] in patients with sensorineural viral infection of the first cranial nerve is an infrequent scenario in the clinical practice and our previous knowledge on neurotrophic viruses is limited. Hence the low prevalence of sensorineural viral anosmia has made clinical research on this topic difficult compounded by the lack of infrastructure to do neuroimaging studies, cumbersome procedures to take histological specimens from olfactory epithelium and absent viral cultivation methods until COVID-19 pandemic. COVID-19 a form of respiratory infection that remains an active pandemic responsible for the death of millions whose clinical course and pathophysiology is still an elusive topic. Over the course of the pandemic multiple studies have been published expressing the incidence of anosmia in COVID-19 patients. Various researchers reported a higher frequency of olfactory symptoms in asymptomatic patients of COVID-19. Though there is shortage of data on anosmia incidence due to COVID-19 in India the studies enlisted in our study may be analysed to fulfil that lacuna. Irrespective of the fact that most of the health organisations worldwide have adapted acute anosmia among symptoms corresponding to COVID19 many of the new reported cases of COVID-19 induced anosmia is under diagnosed. This could be due to various factors but largely because of the lack of understanding of the correlation between corona virus and anosmia and ignorance of anosmia as a symptom among the common as well as medical population. The ways of assessing anosmia are also of paramount importance. It is a well-known fact that objective methods to evaluate olfactory disorders are more reliable than the subjective methods. Most widely used objective techniques for assessing olfaction are- the 
University of Pennsylvania Smell Identification Test (UPSIT), "Sniffing Sticks", test, The Connecticut Chemosensory Clinical Research Centre (CCCRC) test and 12-odor Brief Smell Identification Test (BSIT), otherwise called the Cross-Cultural Smell Identification Test. These tests rely on odour threshold detection and odour identification. Sadly, these tests are seldomly used in the Indian population due to their expensive nature, less familiarity of the odours included in the test among the local masses and availability of these test kits. So, a simple smell identification test employing familiar odours for Indian population is commendable. Other special sensory systems like hearing and vision can be assessed with a gold standard measure but this is not the case for olfaction. A gold standard test for olfactory function would be ideal. But achieving this feat can be difficult, because of the cultural difference for odours and fragrances in different regions. Accepting such differences and adjusting the odorants used in smell tests may provide an alternative way in the absence of gold standard test for olfactory function for comparison of clinical data. Among the screened studies in our review Vijay Bidkar et al. proposed an alternative tool for the community health workers to assess anosmia and taste dysfunction in COVID-19 patients with effectiveness known as COVID-19 Anosmia Reporting Tool. Which was originally developed by American Academy of Otolaryngology-Head and Neck Surgery (AAO-HNS) can be used in addition to the above-mentioned methods to fortify the evidence [26].

SARS-CoV-2 requires double expression of two genes, Angiotensin-Converting Enzyme-2 (ACE2) and Transmembrane Protease Serine2 (TMPRSS2) receptors to enter the host. ACE2 binds to viral spike protein and TMPRSS2 facilitates priming of the $\mathrm{S}$ protein. Both ACE 2 and TMPRSS2 are expressed in the sustentacular cells of human olfactory epithelium and not on the OSN. The functioning of OSN after the sustentacular cells being infected with virus remains largely unknown. However, in the case of asymptomatic carriers, where we do not observe a complete loss of olfaction, the elevated levels of inflammatory cytokines [27] or an ionic imbalance in the sustentacular cells might affect the electrical threshold of OSNs producing olfactory dysfunctions of varying severity [28, 29].

In a Study conducted by Induraj kumar $26.9 \%$ of the patients self-reported anosmia before testing. Whereas after quantitative evaluation the incidence increased to $41.3 \%$. This reflects that incidence of anosmia related to COVID19 would be underestimated in an epidemiological study where only subjective methods were used to assess anosmia (30). Hence objectification of anosmia is essential to prevent under diagnosing it. A meta-analysis was taken as reference in a study done by Nishith Dev [31] to denote the fact that incidence of anosmia increases when validated instruments were used instead of subjective evaluation. Subjective evaluation has been the most common method in assessing the incidences of anosmia in majority of the studies screened in our review as only 4 studies have objective evaluation of anosmia. Similarly, a study by Anindya S. Bhattacharjee [32], used a novel olfactometer to quantify the severity of anosmia reported that out of the $85 \%$ of the anosmic asymptomatic patients in their study only $15 \%$ of them knew about their loss of smell.

Prasun Mishra et al. in his study concluded that the prevalence of anosmia in European population is higher than that of Asian population [33].

The incidence of anosmia as observed in our study as an average can be put to $30.19 \%$. A comparison of this incidence rate with European and East Asian studies was done. A European study done by Klopfenstein et al., which stated an incidence of as $47 \%$ [34]. Another European study by Leichen et al. reported Anosmia was 86\% [35] and Padrino et al. stated $83 \%$ [36]. A meta-analysis done by Tong et al. in Europe gives an incidence of $52.73 \%$ [37]. Although only few studies on the incidence of olfactory dysfunctions in Asia have been published so far. It is noted that the average incidence rate of this study is more or less similar to the findings of other Asian studies. East Asia have shown incidence anosmia to be ranging from $5.6 \%$ patients in China [38], 8.9\% in Japan [39], to 30\% in Korea [40]. Prasun et al. showed that the olfactory dysfunctions were seen in $14.8 \%$ of Indian patients [33]. The prevalence in East Asians is much less as compared to the Caucasians [41], the probable phenomenon behind this difference in the incidence rate between Western and Asian population remains a topic of debate and requires further research. Fortunately, however some potential mechanisms have been postulated.

1. Virus becomes more stable through mutations of surface proteins, spike [S] protein and nucleocapsid $[\mathrm{N}]$ protein reducing its entry into the cell [42]

2. Genetic differences between ethnic groups and their role in viruses affecting organ systems.

3. The affinity of SARS COV-2 for tissues and potential human genetic factors [43].

4. Last but not the least the difference in the degree of expression of ACE2 throughout the body that can affect the outcome [44]. Bilinska et al., concluded that Caucasians might have excessive ACE2 variants expressed on the sustentacular cells of their olfactory cleft, hence resulting in the binding of the SARSCoV-2 virus with higher affinity, resulting in higher frequency olfactory symptoms as compared to the East Asians, who have lesser ACE2 variants [45]. Also, a metanalysis done by Bartheld et al. signifies 
that ethnicity is a pivotal factor in contributing to the difference observed in incidence of chemosensory dysfunction amongst East Asian and Caucasian population as quoted by the study done by Pradip Ranjan [46].

This review focuses the attention to the study done by Kunal Thakur. He found an alarming fact that in the study $72.3 \%$ of the patients had anosmia as the only symptom during the study. The finding stresses the need to enquire about new onset anosmia and smell dysfunction and taste dysfunction as it could be the only symptom or the first symptom to appear in COVID-19 patients. He has concluded that quarantine and isolation measures could be made more effective by early identification of these individuals with smell loss with no other symptoms [47] as supported by Krajewska et al. [7].

Hence, it may be presumed that even though incidence of olfactory dysfunction in study sample is lower than that of European subjects, olfactory dysfunction in COVID-19 cases does form a significant clinical feature. After the detailed literature review, we came to a conclusion that objective analysis of olfactory dysfunction improves the incidence rate of anosmia when compared to subjective methods. Objective methods can quantify olfactory loss and restrict confounders if any present as they are based on true perception of a stimuli hence limiting response and measurement bias. The increased frequency of olfactory loss when an objective methodology is used in a study rather than a subjective method implies that subjective methods might lack vital data and underestimate true smell loss in COVID-19 patients. [30] A close study of the 16 articles has provided valuable information relating to anosmia. They are highlighted in the following heads.

\section{Dysgeusia Associated with Anosmia}

Taste and smell perception are undoubtedly closely related. The Direct damage to nerves in the olfactory epithelium, where ACE2 is expressed in an enormous quantity, can also disrupt the taste mechanics in 2 ways: 1. Directly damaging those cells expressing ACE2, in the peripheral neurosensory taste chemoreceptors complex, 2. Affecting the VII, IX, or X cranial nerves whish are responsible for gustation. Among them, damage to the chorda tympani which is a branch of Facial nerve supplying anterior $2 / 3 \mathrm{rd}$ of the tongue is the most feasible cause. The virus after colonising the nasopharynx, may utilise the eustachian tube as a portal to enter into middle ear, causing further injury to chorda resulting in dysgeusia [48].

\section{Clinical Factors in Anosmia}

Nishanth Dev et al., conducted a case control study involving 261 patients and found in his study that Thrombocytopenia and elevated serum creatinine levels were associated significantly with presence of anosmia or dysgeusia [31]. Also he found association between chemosensory dysfunction and renal derangement. Anvi Jain et al. state that the COVID-19 patients with Olfactory and taste dysfunction had a higher viral load than those without Olfactory and taste dysfunction [49]. A study done by Xiangming et al. was the only study in this vast literature search to expresses a female preponderance of anosmia in COVID-19 [52, 53].

\section{Quantification of Anosmia}

A study conducted by Ananda S. Bhattacharjee, presented a novel method to assess the olfactory fitness of asymptomatic COVID-19 patients diagnosed with SARS-CoV-2 infection. They proposed an olfactory-action meter. It is a ten-channel olfactometer, which can deliver odours with high temporal precision. The instrument delivers odorized air through a glass funnel into an odour delivery unit through which subjects smell different odours. The olfactory function test they proposed challenges the detection abilities of the subjects at the threshold levels and probes olfactory matching skills. The results reflect the damage caused at the sensory periphery level as well as higher olfactory centres due to virus infection. Their custom-made olfactory action meter detected $82 \%$ of asymptomatic patients with olfactory deficits, only $15 \%$ of these patients realized about their loss of sense of smell before participating in the olfactory function test. The disparity between self-reported and quantitative assessment of smell loss clearly determines the necessity to develop effective quantitative investigations to gauge the olfactory deficits in carriers of COVID-19.

The asymptomatic carriers pose the greatest threat epidemiologically. Hence using a quantitative screening tool is mandatory to identify and isolate asymptomatic patients as anosmia may have remained undetected with traditional methods due to lack of sensitivity. [32]

\section{Anosmia Recovery Rate}

The recovery from the anosmia reported in certain studies in the review can be given as a tabular form Table 4. It is evident from the review that the patients suffering from anosmia due to COVID-19 recover their sense of olfaction. 
Table 4 Anosmia recovery pattern observed in the review

\begin{tabular}{|c|c|c|c|c|}
\hline S. no & Name of the study & $\begin{array}{l}\text { Author and year } \\
\text { of the study }\end{array}$ & $\begin{array}{l}\text { Mean number } \\
\text { of days for } \\
\text { recovery }\end{array}$ & $\begin{array}{l}\text { Percentage of } \\
\text { patients } \\
\text { recovered }(\%)\end{array}$ \\
\hline 1 & $\begin{array}{l}\text { Evolution of olfactory and gustatory dysfunctions } \\
\text { in COVID-19 patients in India }\end{array}$ & $\begin{array}{l}\text { Pradipt Ranjan Sahoo } \\
\text { Sep } 2020\end{array}$ & 14 & 92 \\
\hline 2 & $\begin{array}{l}\text { Olfactory and taste dysfunction in coronavirus disease } 2019 \\
\text { patients: its prevalence \& outcomes }\end{array}$ & $\begin{array}{l}\text { A Jain } \\
\text { Sep } 2020\end{array}$ & 14 days & $>90$ \\
\hline 3 & $\begin{array}{l}\text { Otolaryngologic manifestation and long-term outcome in mild } \\
\text { Covid-19: experience from a tertiary care centre in India }\end{array}$ & $\begin{array}{l}\text { Smriti Panda } \\
\text { Oct } 2020\end{array}$ & 28 & 96 \\
\hline 4 & $\begin{array}{l}\text { Evaluation of olfactory acuity in patients with Coronavirus } \\
\text { disease } 2019 \text { (COVID-19) }\end{array}$ & $\begin{array}{l}\text { Naveed Nazir Shah } \\
\text { Oct } 2020\end{array}$ & 14 days & 90 \\
\hline 5 & $\begin{array}{l}\text { Olfactory dysfunction in Covid-19 Patients: findings } \\
\text { from a tertiary rural centre }\end{array}$ & $\begin{array}{l}\text { Kunal Thakur } \\
\text { Jan } 2021\end{array}$ & 14 & 72 \\
\hline
\end{tabular}

The duration and percentage of the patients recovering varies mildly. This excellent recovery from anosmia in a short time span suggests few probable pathologies behind anosmia 1. Competitive action of the virus on the olfactory receptors 2. Local inflammatory phenomenon rather than central 3. Non neural olfactory epithelial cells as the potential targets of SARS COV-2. These theories are Supported by studies included in the review done by Kunal thakur [50], Smriti Panda [51] and A Jain [49]. A review done by Xiangming et al. cited by one of the studies of this review found that patients develop anosmia 4.4 days after the onset of the SARS-CoV-2 infection, with a duration of 8.96 days, and $98 \%$ of patients might recover within 28 days $[52,53]$.

\section{Conclusion}

Smell is one of the important senses and it should not be taken for granted. Though COVID-19 can present asymptomatically, there are a vast number of patients who present with anosmia. In India mostly Subjective evaluation of COVID-19 induced anosmia results is carried out resulting in under reporting of the incidence rates. So, an objective evaluation of anosmia should be taken into consideration to evaluate anosmia. As observed in this study the average incidence of anosmia in Indian population is $13.9 \%$ while in European population it is $86 \%$.

\section{Limitation}

Lack of gold standard test for quantitative assessment of olfaction is evident. Time has arrived where these is a need to practice the formulation of a gold standard test [as in hearing and vision assessment] for proper quantified assessment of sense of smell.

Authors Contribution PA: Conception, Design, Supervision, Material collection,Data collection and/or processing, Analysis and/or interpretation, Literature review, Writing. SA: Design, Supervision, Material collection, Data collection and/or processing,,Analysis and/ or interpretation. SV: Conception, Design, Supervision, Funding, Material collection, Data collection and/or processing, Analysis and/ or interpretation, Writing, Critical review. RR: Conception, Supervision, Material collection, Critical review.

Funding No funding obtained.

\section{Declarations}

Conflicts of interest The author declare that they have no conflict of interest.

\section{References}

1. Chen N, Zhou M, Dong X, Qu J, Gong FHY et al (2020) Epidemiological and clinical characteristics of 99 cases of 2019 novel coronavirus pneumonia in Wuhan, China: a descriptive study. Lancet 395:507-513

2. WHO (2021) WHO coronavirus Disease dashboard. https://covid19. who.int/table.

3. Villalba NL, Maouche YOM (2020) Anosmia and dysgeusia in the absence of other respiratory diseases: should COVID-19 infection be considered? Eur J Case Rep Intern Med 4(7):001641

4. Harris PA, Taylor R, Thielke R, Payne J, Gonzalez NCJ (2009) Research electronic data capture (REDCap) - a metadata driven methodology and workflow process for providing translational research informatics support. J Biomed Inf 42(2):377-81

5. Wu Y, Xu X, Chen Z, Duan J, Hashimoto K, Yang L et al (2020) Nervous system involvement after infection with COVID-19 and other coronaviruses. Brain Behav Immun (Internet) 87:18-22. https://doi.org/10.1016/j.bbi.2020.03.031

6. Guan W, Ni Z, Hu Y (2020) Clinical characteristics of coronavirus disease 2019 in China. N Engl J Med 382:1708-1720 
7. Krajewska J, Krajewski W, Zub KZT (2020) COVID-19 in otolaryngologist practice: a review of current knowledge. Eur Arch Oto-Rhino-Laryngol 277:1885-1897

8. Keller AMD (2013) Hidden consequences of olfactory dysfunction: a patient report series. BMC ear nose throat Dis 1(13):8

9. Deems DA, Doty RL, Settle RG, Moore-Gillon V, Shaman P, Mester AF et al (1991) Smell and taste disorders, a study of 750 patients from the university of pennsylvania smell and taste center. Arch Otolaryngol Neck Surg 117(5):519-528

10. Nordin SBA (2008) Complaints of olfactory disorders: epidemiology, assessment and clinical implications. Allergy Clin Immunol 1(8):10-15

11. Van Riel D, Verdijk RKT (2015) The olfactory nerve: a shortcut for influenza and other viral diseases into the central nervous system. J Pathol 2(235):277-287

12. Vaira LA, Salzano G, Deiana GDRG (2020) Anosmia and ageusia: common findings in COVID-19 patients. Laryngoscope 7(130): 1787

13. Suzuki M, Saito KMW (2007) Identification of viruses in patients with postviral olfactory dysfunction. Laryngoscope 2(117):272-277

14. Centers for Disease Control and Prevention (2020) Coronavirus disease 2019 (COVID-19)—symptoms. Published April 17, 2020. https://www.cdc.gov/coronavirus/2019-ncov/symptoms-testing/ symptoms.html Accessed 22 Apr 2020

15. Ralli M, Di Stadio AGA et al (2020) Defining the burden of olfactory dysfunction in COVID-19 patients. Eur Rev Med Pharmacol Sci 7(24):3440-3441

16. Brann DH, Tsukahara TWC (2020) Non-neuronal expression of SARS-CoV-2 entry genes in the olfactory system suggests mechanisms underlying COVID-19-associated anosmia. Sci Adv 6(31):5801

17 Malnic B, Godfrey PA, Buck BL (2004) The human olfactory receptor gene family. Proc Natl Acad Sci USA 101:2584-9

18. Lapid H, Shushan S, Plotkin A, Voet H, Roth Y, Hummel T (2011) Neural activity at the human olfactory epithelium reflects olfactory perception. Nat Neurosci 11(14):1455-U132

19. Hoffmann M, Kleine-Weber H, Schroeder S, Kruger N, Herrler TES (2020) SARS-CoV-2 cell entry depends on ACE2 and TMPRSS 2 and is blocked by a clinically proven protease inhibitor. Cell 2(182):271-280

20 Koul D, Begh RA, Kalsotra P (2021) Olfactory and Gustatory alterations in COVID-19 patients: a tertiary care COVID-19 centre inpatient experience. Indian J Otolaryngol Head Neck Surg. https://doi.org/10.1007/s12070-021-02397-z

21. Fodoulian L, Tuberosa J, Rossier D, Landis BN, Carleton A RI (2020) SARS-CoV-2 receptor and entry genes are expressed by sustentacular cells in the human olfactory neuroepithelium. May 30, 2020. Availablefrom:https://www.researchgate.net/deref/ https3A\%2F\%2Fdoi.org\%2F10.1101\%2F2020.03.31.013268

22 Yan R, Zhang Y, Li Y (2020) Structural basis for the recognition of SARS-CoV-2 by full-length human ACE2. Science(80-) 367:1444-8

23. Wrapp D, Wang NCK (2020) Cryo-EM structure of the 2019-nCoV spike in the prefusion conformation. Science 367:1260-3

24. Mair M, Singhavi H, Pai A, Singhavi J, Gandhi P, Conboy P, Baker A, Das S (2020) A meta-analysis of 67 studies with presenting symptoms and laboratory tests of COVID-19 patients. Laryngoscope. https://doi.org/10.1002/lary.29207

25. Prakash A, Singh H, Sarma P et al (2020) nCoV-2019 infection induces neurological outcome and manifestation, linking its historical ancestor SARS-CoV \& MERS-CoV: A systematic review and meta-analysis, 17 June 2020; PREPRINT (Version 1) Doi: https://doi.org/10.21203/rs.3.rs-35790/v1
26. Bidkar V, Mishra M, Selvaraj K, Joshi P, Shrikrishna BH, Dabhekar S et al (2020) Testing olfactory and gustatory dysfunctions among quarantine COVID-19 suspects. Indian J Otolaryngol Head Neck Surg. https://doi.org/10.1007/s12070-020-02210-3

27. Torabi A, Mohammadbagheri E, Dilmaghani NA, Bayat AH, Fathi M, Vakili K et al (2020) Proinflammatory cytokines in the olfactory mucosa result in COVID-19 induced anosmia. ACS chem neurosci 13(11):1909-13

28 Cooper KW, Brann DH, Farruggia MC, Bhutani S, Pellegrino R, Tsukahara $\mathrm{T}$ et al (2020) COVID-19 and the chemical senses: supporting players take center stage. Neuron 13(11):219-33

29 Vogalis F, Hegg CCLM (2005) Ionic conductances in sustentacular cells of the mouse olfactory epithelium. Physiol-lond 562(3):785-99

30 Rajkumar I, Anand KH, Revathishree K, Shoba K, Srinivasan K (2020) Contemporary analysis of olfactory dysfunction in mild to moderate COVID 19 patients in a tertiary health care centre. Indian J Otolaryngol Head Neck Surg. https://doi.org/10.1007/s12070-020-02175-3

31. Dev N, Sankar J, Gupta N et al (2021) COVID-19 with and without anosmia or dysgeusia: a case-control study. J Med Virol. https://doi.org/10.1002/jmv.26784

32 Bhattacharjee AS, Joshi SV, Naik S, Sangle S, Abraham NM (2020) Quantitative assessment of olfactory dysfunction accurately detects asymptomatic COVID-19 carriers. EClinicalMedicine

$28: 100575$. https://doi.org/10.1016/j.eclinm.2020.100575

33 Mishra P, Gowda V, Dixit S, Kaushik M (2020) Prevalence of new onset anosmia in COVID-19 patients: is the trend different between european and indian population? Indian J Otolaryngol Head Neck Surg 72(4):484-7. https://doi.org/10.1007/s12070-020-01986-8

34. Klopfenstein T, Kadiane-Oussou NJTL (2020) Features of anosmia in COVID-19. Med Mal Infect 5(50):436-439

35. Lechien JR, Chiesa-Estomba CM, Hans S, Barillari MRJ, JouffeSaussez LS (2020) Loss of smell and taste in 2013 European patients with mild to moderate COVID-19. Ann Intern 173(8):672-675

36. Paderno A, Mattavelli DRV et al (2020) Olfactory and gustatory outcomes in COVID-19: a prospective evaluation in nonhospitalized subjects. Otolaryngol Head Neck Surg 163(6):1144-1149

37. Tong JY, Wong A, Zhu D, Fastenberg JHTT (2020) The prevalence of olfactory and gustatory dysfunction in COVID-19 patients: a systematic review and meta-analysis. Otolaryngol 163(1):3-11

38. Mao L, Jin H, Wang M, Hu Y, Chen S, He Q, Chang J, Hong C, Zhou Y, Wang D, Miao X, Li Y, Hu B (2020) Neurologic manifestations of hospitalized patients with coronavirus disease 2019 in Wuhan. China JAMA Neurol 77(6):683-690

39. Junpei Komagamine, Taku Yabuki (2020) Initial symptoms of patients with coronavirus disease 2019 in Japan. Doi: https://doi.org/10.21203/rs.3.rs-33323/v1

40. Rabin RC (2020) Lost sense of smell may be a peculiar clue to corona virus infection. New York Times 3- 22. Available from: https://www.nytim es.com/2020/03/22/health/coronavirus-symptoms-smell-taste .html

41. Strafella C, Caputo V, Termine A et al (2020) Analysis of ACE2 genetic variability among populations highlights a possible link with COVID19-related neurological complications. Genes. https://doi.org/10.21203/rs.3.rs-28871/v1

42 Benvenuto D, Giovanetti M, Ciccozzi A, Spoto S, Angeletti S, Ciccozzi M (2020) The new coronavirus epidemic evidence for virus evolution. J Med Virol 4(92):455-9

43. Lechien JR, Chiesa-Estomba CM, De Siati DR et al (2020) Olfactory and gustatory dysfunctions as a clinical presentation of mild-to-moderate forms of the coronavirus disease (COVID-19): 
a multicenter European study. Eur Arch Otorhinolaryngol 277(8):2251-2261

44. Li W, Zhang CSJ et al (2020) Receptor and viral determinants of SARS-coronavirus adaptation to human ACE2. EMBOJ 8(24):1634-43

45. Bilinska K, Jakubowska P, Von Bartheld CS, Butowt R (2020) Expression of the SARS-CoV-2 entry proteins, ACE2 and TMPRSS2, in cells of the olfactory epithelium: identification of cell types and trends with age. ACS Chem Neurosci 11(11):1555-1562

46. Sahoo PR, Sahu M, Surapaneni PS, Maiti A, Vankamamidi R, Panda N, Biswal RN (2021) Evolution of olfactory and gustatory dysfunctions in COVID-19 patients in India. Eur Arch Otorhinolaryngol $3: 1-7$

47. Beltra'n-Corbellini A et al (2020) Acute-onset smell and taste disorders in the context of COVID-19: a pilot multicentre polymerase chain reaction based case-control study. Eur J Neurol 9(27):1738-41

48. Keyhan SO, Fallahi HR, Cheshmi B (2020) Dysosmia and dysgeusia due to the 2019 novel coronavirus; a hypothesis that needs further investigation. Maxillofac Plast Reconstr Surg 42:9. https://doi.org/10.1186/s40902-020-002547

49. Jain A, Kumar L, Kaur J, Baisla T, Goyal P, Pandey AK et al (2020) Olfactory and taste dysfunction in coronavirus disease
2019 patients: Its prevalence and outcomes. J Laryngol Otol 134(11):987-91

50 Thakur K, Sagayaraj A, Prasad KC, Gupta A (2021) Olfactory dysfunction in COVID-19 patients findings from a tertiary rural centre. Indian J Otolaryngol Head Neck Surg. https://doi.org/10.1007/s12070-021-02364-8

51 Panda S, Mohamed A, Sikka K, Kanodia A, Sakthivel P, Thakar A et al (2020) Otolaryngologic manifestation and long-term outcome in mild COVID-19: experience from a tertiary care centre in India. Indian J Otolaryngol Head Neck Surg. https://doi.org/10.1007/s12070-020-02217-w

52. Hüttenbrink KB, Hummel T, Berg D, Gasser T, Hähner A (2013) Riechstörungen: Häufig im alter und wichtiges frühsymptom neurodegenerativer erkrankungen. Dtsch Arztebl Int $110(1-2): 1-8$

53. Meng X, Deng Y, Dai Z, Meng Z (2020) COVID-19 and anosmia: a review based on up-to-date knowledge. Am J Otolaryngol 41(5):102581. https://doi.org/10.1016/j.amjoto.2020.102581

Publisher's Note Springer Nature remains neutral with regard to jurisdictional claims in published maps and institutional affiliations. 